\title{
Evidence of the impact of deep convection on reactive Volatile Organic Compounds in the upper tropical troposphere during the AMMA experiment in West Africa
}

\author{
J. Bechara ${ }^{1}$, A. Borbon ${ }^{1}$, C. Jambert ${ }^{1, *}$, A. Colomb ${ }^{1, * *}$, and P. E. Perros ${ }^{1}$ \\ ${ }^{1}$ Laboratoire Interuniversitaire des Systèmes Atmosphériques, UMR CNRS 7583, Universités Paris Diderot and Paris Est, \\ Créteil, France \\ *now at: Laboratoire d'Aérologie (LA), Université Paul Sabatier, CNRS, Toulouse, France \\ ** now at: Laboratoire de Métrologie Physique (LaMP), CNRS, Université Blaise Pascal, Aubière, France
}

Received: 18 July 2009 - Published in Atmos. Chem. Phys. Discuss.: 29 September 2009

Revised: 26 September 2010 - Accepted: 8 October 2010 - Published: 4 November 2010

\begin{abstract}
A large dataset of reactive trace gases was collected for the first time over West Africa during the African Monsoon Multidisciplinary Analysis (AMMA) field experiment in August 2006. Volatile Organic Compounds (VOC from C5-C9) were measured onboard the two French aircrafts the ATR- 42 and the Falcon- 20 by a new instrument AMOVOC (Airborne Measurement Of Volatile Organic Compounds). The goal of this study is (i) to characterize VOC distribution in the tropical region of West Africa (ii) to determine the impact of deep convection on VOC distribution and chemistry in the tropical upper troposphere (UT) and (iii) to characterize its spatial and temporal extensions. Experimental strategy consisted in sampling at altitudes between 0 and $12 \mathrm{~km}$ downwind of Mesoscale Convective Systems (MCS) and at cloud base. Biogenic and anthropogenic VOC distribution in West Africa is clearly affected by North to South emission gradient. Isoprene, the most abundant VOC, is at maximum level over the forest $(1.26 \mathrm{ppb})$ while benzene reaches its maximum over the urban areas $(0.11 \mathrm{ppb})$. First, a multiple physical and chemical tracers approach using $\mathrm{CO}, \mathrm{O}_{3}$ and relative humidity was implemented to distinguish between convective and nonconvective air masses. Then, additional tools based on VOC observations (tracer ratios, proxy of emissions and photochemical clocks) were adapted to characterize deep convection on a chemical, spatial and temporal basis. VOC vertical profiles show a "C-shaped" trend indicating that VOCrich air masses are transported from the surface to the UT
\end{abstract}

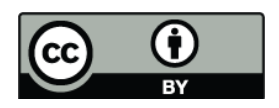

Correspondence to: A. Borbon (agnes.borbon@lisa.u-pec.fr) by deep convective systems. VOC mixing ratios in convective outflow are up to two times higher than background levels even for reactive and short-lived VOC (e.g. isoprene up to $0.19 \mathrm{ppb}$ at $12 \mathrm{~km}$-altitude) and are dependent on surface emission type. As a consequence, UT air mass reactivity increases from $0.52 \mathrm{~s}^{-1}$ in non-convective conditions to $0.95 \mathrm{~s}^{-1}$ in convective conditions. Fractions of boundary layer air contained in convective outflow are estimated to be $40 \pm 15 \%$. Vertical transport timescale is calculated to be $25 \pm 10$ min between 0 to $12 \mathrm{~km}$ altitude. These results characterize deep convection occurring over West Africa and provide relevant information for tropical convection parameterization in regional/global models.

\section{Introduction}

Tropospheric ozone $\left(\mathrm{O}_{3}\right)$ plays an essential role in determining the oxidizing capacity of the atmosphere and contributes largely to the global greenhouse effect. It is a major tropospheric oxidant and controls global atmospheric chemistry. Tropospheric ozone production is considered to be mainly driven by carbon monoxide (CO) and volatile organic compounds (VOC) oxidation in presence of nitrogen oxides $\left(\mathrm{NO}_{\mathrm{x}}\right)$ and sunlight. Trace gases originate from both biogenic and anthropogenic emissions. Tropical regions are major sources of these ozone precursors and undergo intensive solar radiation. This induces highly active photochemistry leading to high ozone formation (Kesselmeier et al., 2000; Guenther et al., 2006; Saxton et al., 2007). Nevertheless, the ozone budget is not well established yet over these regions due to complex coupling between chemical

Published by Copernicus Publications on behalf of the European Geosciences Union. 
processes and dynamics. Indeed, significant deviations exist between observed and modeled global distribution of ozone in tropical regions (Martin et al., 2002; Stevenson et al., 2006). Moreover, modeling studies show discrepancies in ozone budgets when air masses are subject to deep convective events. Some studies show an increase of up to $12 \%$ in the global ozone burden due to convective transport of gaseous precursors (Lawrence et al., 2003) while others show a decrease of 13 to $20 \%$ (Doherty et al., 2005; Lelieveld and Crutzen, 1994). In fact, all these studies highlight that convective transport of gaseous precursors exhibit a critical impact on tropospheric ozone budget. In the last two decades, some observational campaigns have been conducted worldwide to better understand the role of deep convection and its efficiency to transport gaseous species from the boundary layer to the upper troposphere (UT). Many studies over midlatitudes (Dickerson et al., 1987; Hauf et al., 1995; Pickering et al., 1988) showed that deep convection could pump low tropospheric air to the tropopause region and proved effective transport of trace gases (e.g. CO, $\mathrm{O}_{3}$; Ström et al., 1999; Fischer et al., 2003) even highly reactive and short-lived (e.g. VOC, Colomb et al., 2006; Stickler et al., 2006). More recently, a few campaigns above the tropical Amazonian forest (Warneke et al., 2001; Ganzeveld et al., 2008; Stickler et al., 2007) showed important influence of deep convection on VOC such as isoprene and formaldehyde. All these field observations reported that UT trace gas levels related to convective events were significantly higher than background levels. Generally, updrafts in deep convective systems have vertical speeds of 5 to $15 \mathrm{~m} \mathrm{~s}^{-1}$ transporting air masses from low troposphere (LT) to the UT in about $30 \mathrm{~min}$ (Thompson et al., 1997; Houze, 2004). Mixing, chemical loss and deposition appear negligible during vertical transport for major species like $\mathrm{CO}, \mathrm{NO}_{\mathrm{x}}$ and $\mathrm{VOC}$ (methane, alkanes, alkenes, aromatics...). Finally, deep convection acts as an additional source of reactive trace gases in the middle and upper troposphere by fast injections at various levels including cloud top, e.g. $10-15 \mathrm{~km}$ or more. Indeed, when rapidly transported to the UT, atmospheric lifetimes of reactive trace gases are longer (Dickerson et al., 1987; Poisson et al., 2000) due to temperature decrease and lower $\mathrm{OH}$ concentrations. As a consequence, trace gases will persist longer, leading to delayed $\mathrm{O}_{3}$ formation (Dickerson et al., 1987). Gases with longer lifetimes (e.g. CO) can also travel far from source region due to higher wind speeds expanding the spatial scale of their influence on $\mathrm{O}_{3}$ and $\mathrm{HO}_{\mathrm{x}}$ radicals production. But, models to observations deviations have highlighted the lack of understanding of chemical and dynamical processes in tropical regions and the paucity of observations in these areas (Lelieveld and Crutzen, 1994; Lawrence et al., 2003; Doherty et al., 2005). Therefore, it is essential to collect new in-situ observation on atmospheric composition in tropical regions in order to better characterize on-going chemical and dynamical processes.
West Africa has been poorly explored up to now. It is a particularly sensitive region because of its location in the tropical belt and its contrasted land-surface characteristics (from bare soils in the Sahel to dense vegetation in the tropical forest) as well as dynamical, chemical and human interactions that modulate significantly trace gases distribution and fate. West Africa is particularly sensitive during the monsoon season, when occurrence of mesoscale convective systems (MCS) is most recurrent (Houze, 2004; Zipser et al., 2006). The West African monsoon is due to several winds converging toward the Inter Tropical Convergence Zone (ITCZ) caused by the intense solar heating of the equatorial zone. In the low layers (up to $3 \mathrm{~km}$ ), a continental north- easterly wind (Harmattan), warm and dry, converges with a southwesterly wet and colder wind (monsoon flow). In the middle troposphere, a distinct layer is established between 3 and $4 \mathrm{~km}$ by the African Easterly Jet (AEJ) around $15^{\circ} \mathrm{N}$ which is an intense current reaching its utmost during the wet season. The AEJ allows westward air mass transport. In the UT, another westward current, the Tropical Easterly Jet (TEJ), flows above the Sahel at about $16 \mathrm{~km}$ altitude during the wet season (Lafore and Moncrieff, 1989; Nicholson, 2009).

The African Monsoon Multidisciplinary Analysis (AMMA) is an international program that aims to improve our knowledge and understanding of the West African monsoon and its variability. One of AMMA objectives is to determine the chemical composition of the middle and upper troposphere connected to deep convection events and to assess the ozone budget over West Africa (Mari and Prospero, 2005; Redelsperger et al., 2006). A Special Observation Period (SOP 2a2) took place in July and August 2006 during the monsoon season to fulfill these objectives. An overall review of the SOP is related in Reeves et al., 2010). Within this framework, the purpose of our study is (i) to characterize VOC vertical and latitudinal distribution in the tropical troposphere over West Africa (ii) to determine the impact of deep convection on VOC distribution and chemistry in the tropical UT and (iii) to characterize its spatial and temporal extensions. This work is based on airborne observations of trace gases and reactive VOC, collected on board the two French aircrafts, the ATR-42 and the Falcon-20 in August 2006. Various diagnostic tools (dynamical and chemical tracers, VOC tracer ratios, emission proxy, photochemical clocks) are set up and used together to investigate the impact of deep convection and its spatial and temporal characteristics. Section 2 illustrates briefly the campaign. Section 3 describes the instrumental set up. Section 4 reports VOC observations and their spatial distribution over the domain. Section 5 establishes a set of conditions by using $\mathrm{CO}, \mathrm{O}_{3}$ and relative humidity ( $\mathrm{RH}$ ) as convection indicators to distinguish non-perturbed conditions from those perturbed by convection. Section 6 assesses the impact of deep convection on trace gases and evaluates its characteristics on the basis of VOC observations. 


\section{Field campaign and experimental strategy}

SOP $2 \mathrm{a} 2$ took place in August 2006 during the monsoon season in West Africa. Measurements were performed by both French research aircraft ATR-42 and F-F20 based in Niamey (Niger) and operated by the French Service of Instrumented Aircraft for Environmental Research (SAFIRE). Flights were carried out between the 2 and 21 August. The ATR-42 and FF20 conducted 18 and 10 research flights respectively, of 3 to $4 \mathrm{~h}$ each, from surface to $12 \mathrm{~km}$. Flight details are reported in Table 1 and F-F20 flight tracks are shown in Fig. 1. Observations cover the region from $2^{\circ} \mathrm{N}$ to $21^{\circ} \mathrm{N}$ and from $10^{\circ} \mathrm{W}$ to $7^{\circ} \mathrm{E}$. The domain displays different surface types with a strong North-to-South vegetation gradient around $12^{\circ} \mathrm{N}$. Above these latitudes, the surface presents almost bare soils to a sahelian type. Below $12^{\circ} \mathrm{N}$, the surface presents an important tree coverage and vegetated surface. Main urban sites are Niamey $\left(13.5^{\circ} \mathrm{N}, 2.1^{\circ} \mathrm{E}\right)$ in Niger and Cotonou $\left(6.3^{\circ} \mathrm{N}\right.$, $2.4^{\circ} \mathrm{E}$ ) in south Benin.

Flights fulfilled two objectives: (1) determination of the horizontal and vertical distribution of trace gases and (2) characterization of the air composition affected by MCS. Deploying two aircraft aimed at maximizing the horizontal and vertical geographical coverage of the region. The ATR-42 platform was set up to sample the LT up to $6 \mathrm{~km}$ and to perform flights before and after the passage of MCS. The FF20 platform was used to sample the middle and upper troposphere up to $12 \mathrm{~km}$ and to explore MCS outflow undertaking several flight tracks at increasing distances from the cloud anvil. Flights were planned according to meteorological forecast reports carried out by ACMAD (African Centre of Meteorological Application for Development) as well as MCS tracking using Meteosat-IR images. On 11, 14, 15 and 17 August, four MCS passed over Niamey and were explored by the F-F20. On 18 August, an MCS passed over Niamey. The convective region was explored by the ATR-42 and the F-F20 the day after (19 August). On 13 and 16 August, FF20 flights were performed in clear conditions as reference cases. Other flights by both aircrafts performed horizontal tracks down to Cotonou and over Gulf of Guinea.

\section{Aircraft instrumentation}

The French aircraft were both equipped with instrumentation to measure major trace gases: $\mathrm{CO}, \mathrm{O}_{3}, \mathrm{NO}_{\mathrm{x}}\left(\mathrm{NO}+\mathrm{NO}_{2}\right)$, and VOC (formaldehyde and non-methane hydrocarbons (NMHC) from C5-C9 including alkanes, alkenes and aromatic compounds). Table 2 describes the instrumentation characteristics. NMHC were collected on cartridges using a new offline automatic sampler AMOVOC (Airborne Measurement Of Volatile Organic Compounds) developed at LISA (Bechara et al., 2008). AMOVOC was deployed simultaneously on both aircrafts. About 200 cartridges were collected using AMOVOC during SOP 2a2. AMOVOC

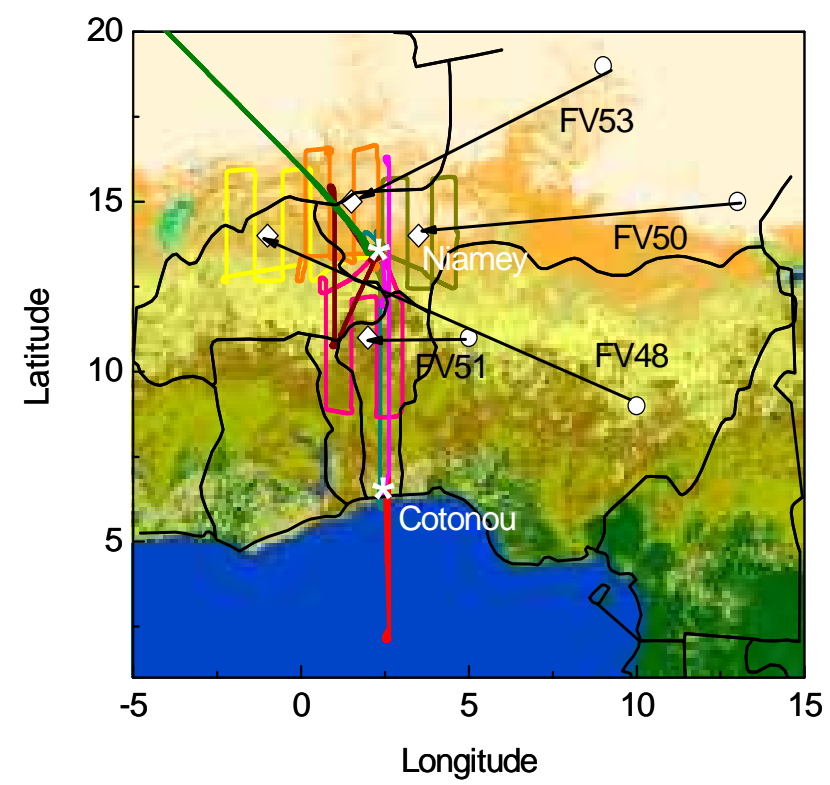

Fig. 1. Explored area during AMMA SOP 2a2. The map reflects the land-surface coverage. Light yellow indicate sahelian type surface. Orange denotes semi-desert region. Light green indicates savanna. Dark green stands for tropical forest. Flights tracks performed by the F-F20 are displayed. The round markers are the locations where each explored MCS started to develop (called latitude zero). The diamond markers are the position where the MCS was explored. The arrows indicate the trajectory of the MCS.

performs $10 \mathrm{~min}$ integrated in-situ sampling on solid adsorbents (Carbosieve SIII, Carbopack B, Carbotrap C) at preselected times intervals. Sampling is performed during horizontal flight tracks at $200 \mathrm{~mL} \mathrm{~min}^{-1}$ flow rate. Samples were shipped to the laboratory in Creteil, France and analyzed by TDAS/GC-MS (Chromtech/Varian). Details of analytical procedures are also given by Bechara et al., 2008). In addition, state parameters of temperature, pressure and aircraft position (altitude, latitude and longitude), irradiance and relative humidity were measured using the standard Safire aircraft instrument package. For most of the instruments, signals were recorded at $1 \mathrm{~Hz}$ frequency.

\section{NMHC distribution}

Air samples were collected throughout the tropospheric column from surface level up to $12 \mathrm{~km}$. 18 NMHC (C5 to C9) comprising alkanes, alkenes and aromatics have been identified and quantified during AMMA. Collected NMHC cover three classes of reactivity (Carter, 1994). The most reactive compounds (due to $\mathrm{OH}$ radical) with a short lifetime $<1$ day are isoprene, pentenes, xylenes and trimethylbenzenes. Lifetime of these compounds is especially governed by photochemistry. Compounds with intermediate lifetimes of 1 to 3 days are $\mathrm{C} 5-\mathrm{C} 8$ alkanes, toluene and 
Table 1. Details on ATR-42 and F-F20.

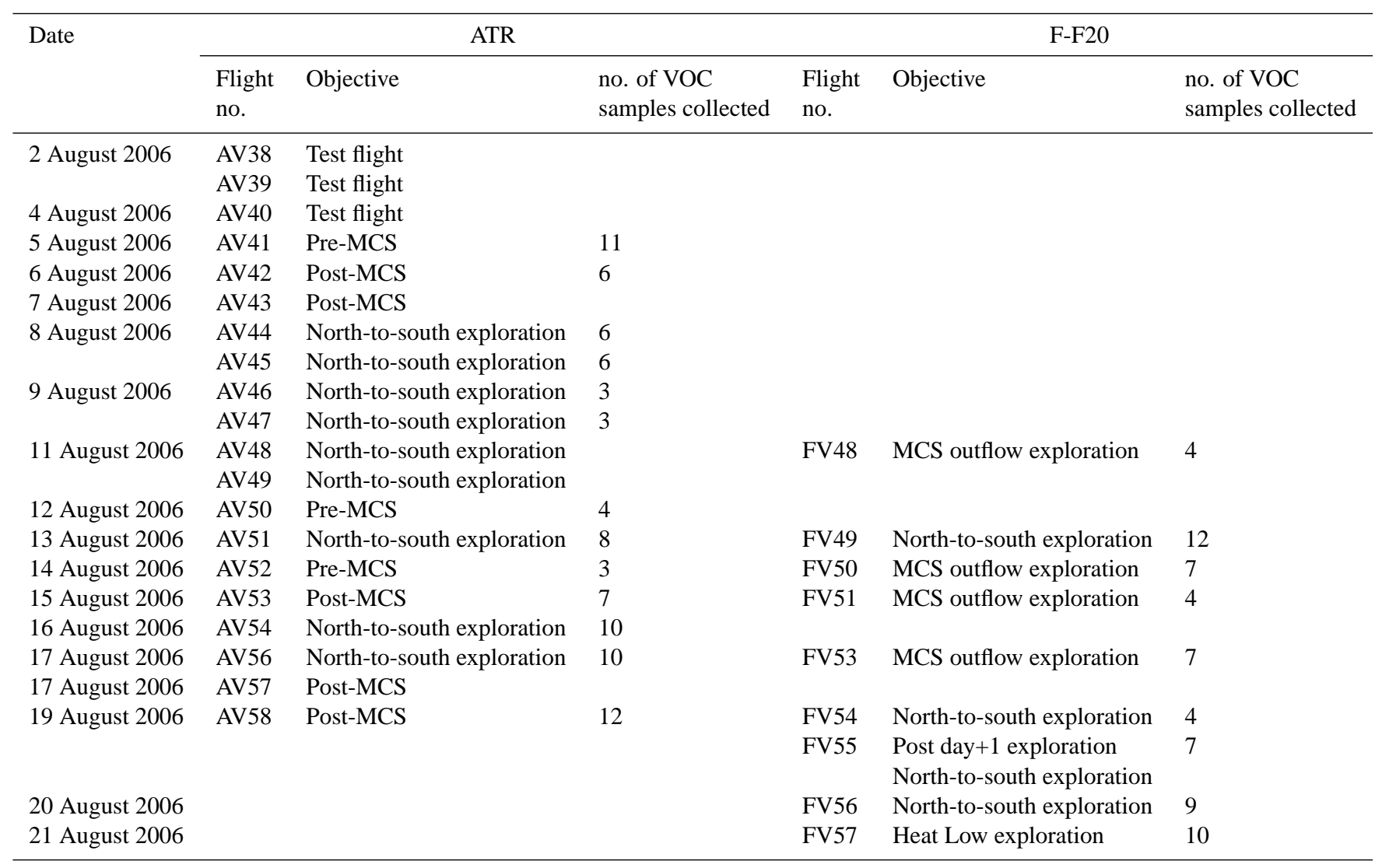

Table 2. Aircraft instrumentation.

\begin{tabular}{|c|c|c|c|c|c|c|c|c|}
\hline Compound & Platform & Instrument & Measurement technique & Time response & $\begin{array}{l}\text { Detection } \\
\text { limit }\end{array}$ & Precision & Accuracy & Reference \\
\hline \multirow[t]{2}{*}{$\mathrm{O}_{3}$} & ATR-42 & Thermo-Electron TEI 49 & \multirow[t]{2}{*}{ UV absorption } & $3 \mathrm{~s}$ & $1 \mathrm{ppb}$ & $1 \mathrm{ppb}$ & & \multirow[t]{2}{*}{ SAFIRE www.safire.fr } \\
\hline & F-F20 & MOZART Instrument & & $4 \mathrm{~s}$ & $2 \mathrm{ppb}$ & $2 \mathrm{ppb}$ & $2 \%$ & \\
\hline \multirow[t]{2}{*}{$\mathrm{CO}$} & ATR-42 & Thermo-Electron $48 \mathrm{CS}$ & \multirow[t]{2}{*}{ IR absorption } & $5 \mathrm{~s}$ & $20 \mathrm{ppb}$ & $20 \mathrm{pbb}$ & & SAFIRE www.safire.fr \\
\hline & F-F20 & MOZART Instrument & & $30 \mathrm{~s}$ & $10 \mathrm{ppb}$ & $5 \mathrm{ppb}$ & $5 \%$ & Nedelec et al., 2003 \\
\hline NMHC & ATR-42/F-F20 & AMOVOC/TDAS/GC-MS & Solid sorbent cartridges & $10 \mathrm{~min}$ & $1-5 \mathrm{ppt}$ & $8-18 \%$ & $1-5 \%$ & Bechara et al., 2008 \\
\hline
\end{tabular}

ethylbenzene. These compounds can undergo photochemistry and transport concurrently. The least reactive compound with relatively long lifetime $>3$ days is benzene (lifetime $\sim 9$ days). Its concentration is primarily controlled by mixing and transport. Observed C5-C9 hydrocarbon concentrations ranged from $1.26 \mathrm{ppb}$ (for isoprene) near the surface to values below detection limits (DL) (1-5 ppt). The most abundant NMHC and their mean values are: isoprene $(0.17 \mathrm{ppb})$, toluene $(0.16 \mathrm{ppb})$ and hexane $(0.13 \mathrm{ppb})$ in the LT and ethylbenzene $(0.18 \mathrm{ppb})$, hexane $(0.13 \mathrm{ppb})$ and toluene $(0.13 \mathrm{ppb})$ in the UT. Only $5 \%$ of the collected samples have values below DL.

\subsection{NMHC latitudinal patterns}

Figure 2 illustrates the north to south variability of some representative biogenic (isoprene) and anthropogenic NMHC (trans-2-pentene being the most reactive NMHC and benzene being the least reactive one, Carter, 1994). Land surface impact on NMHC mixing ratio variability is determined by considering data at altitudes below $2 \mathrm{~km}$-altitude. Average mixing ratios and corresponding standard deviations over $1^{\circ}$ latitudinal bins are reported in Fig. 2 using the log-normal distribution for statistical treatment. The number of samples in each latitude bin varies between $1\left(\right.$ at $\left.7^{\circ} \mathrm{N}\right)$ and 32 


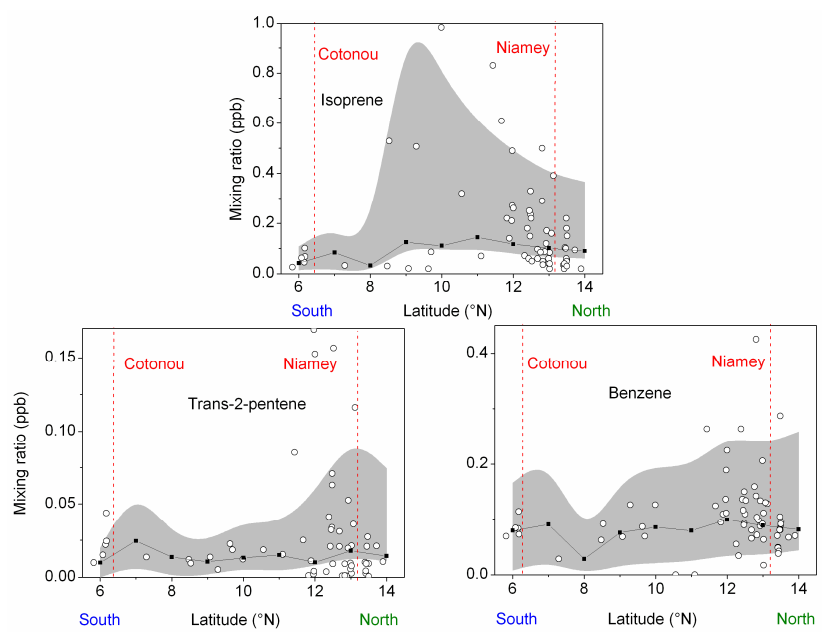

Fig. 2. North-to-South variability profiles of biogenic and anthropogenic NMHC in the low troposphere $(<2 \mathrm{~km})$. Samples are collected on-board the ATR-42. Top panel shows isoprene, bottom left panel shows trans-2-pentene and down right shows benzene. Open markers denote all observations. Solid markers represent the average value in each latitudinal bins of $1^{\circ}$ latitude. Grey area represents standard deviations for all observations.

$\left(\right.$ at $\left.12^{\circ} \mathrm{N}\right)$. Standard deviation will then reflect the variability as well as the number of samples collected. Biogenic and anthropogenic compounds show an opposite pattern due to surface characteristics.

Isoprene concentrations are at constant level (about $0.20 \mathrm{ppb}$ ) between 14 and $11^{\circ} \mathrm{N}$. Then, they show a clear increase between 11 and $7^{\circ} \mathrm{N}$ to about $0.40 \mathrm{ppb}$ over the forest areas. At lower latitude, around Cotonou $\left(6.3^{\circ} \mathrm{N}\right)$ and over the ocean, isoprene levels decrease to less than $0.10 \mathrm{ppb}$ between 7 and $5^{\circ} \mathrm{N}$. This trend clearly shows that biogenic isoprene is modulated by the vegetation gradient observed in West Africa.

Anthropogenic NMHC variability shows the highest concentrations values (around $0.11 \mathrm{ppb}$ for benzene and $0.05 \mathrm{ppb}$ for trans-2-pentene) near urban sites (Cotonou at $6.3^{\circ} \mathrm{N}$ and Niamey at $\left.13.5^{\circ} \mathrm{N}\right)$. Mean levels decrease above the forest between 11 and $7^{\circ} \mathrm{N}$ reaching about $0.06 \mathrm{ppb}$ for benzene and $0.02 \mathrm{ppb}$ for trans-2-pentene. The trans-2-pentene decrease is more pronounced than benzene due to its higher reactivity.

Finally, LT content is tightly related to surface coverage. The contrasted surface coverage is a key factor influencing NMHC concentration gradients in West Africa.

\subsection{NMHC vertical patterns}

Vertical profiles for a selection of representative NMHC are plotted in Fig. 3. All observations as well as mean values in $1 \mathrm{~km}$ altitudinal bins are reported. The number of samples in each altitude bin varies between 4 and 51. Average mixing ratios and corresponding standard deviation in each altitude bin are calculated using log-normal distribution. The magnitude of standard deviation reflects the variability and the number of samples collected in each bin. Mixing ratios in air masses below $2 \mathrm{~km}$-altitude show a large variability depicting the influence of surface emissions (Sect. 4.1). In the mid troposphere, mixing ratios tend to decrease with altitude. But, the vertical gradient is not of similar magnitude and shape for the different species.

Short-lived compounds exhibit a decrease with altitude (e.g. isoprene, trans-2-pentene). Relatively long-lived compounds (few days) show a homogeneous vertical profile (e.g. pentane, benzene, toluene, hexane in Fig. 3) attesting of the well-mixed column and the redistribution of surface emission in the higher layers.

A distinct layer is detected between 3 and $4 \mathrm{~km}$. In this layer significant concentrations are measured. At this level, air masses are attributed to AEJ transporting air masses from the East (e.g. from Chad, Soudan). Another marked layer is met at about $9 \mathrm{~km}$ with high concentrations of pentane, benzene, toluene, hexane, octane, xylenes, ethylbenzene and trimethylbenzenes. These compounds that could originate from biomass burning (Hao et al., 1996; Karl, 2007) indicate biomass burning plumes that were crossed around Cotonou on 19 August. It is also consistent with $\mathrm{CO}$ enhancements (Mari et al., 2008; Ancellet et al., 2008). These plumes come from the Southern Hemisphere where biomass burning is intense during this period.

In the UT $(10-12 \mathrm{~km})$, samples with high mixing ratios even for short-lived NMHC are encountered conferring a "C"-shaped profile to the NMHC vertical distribution. For instance, the reactive isoprene is detected at a maximum of $0.20 \mathrm{ppb}$ on-board the F-F20 at $12 \mathrm{~km}$-height even though it was thought to be present only near the surface where biogenic sources are important (Sect. 4.1). Moreover, shortlived aromatic compounds (1,2,3-trimethylbenzene (Fig. 3), show high concentrations in the UT compared to LT levels. Additional enrichment by long range transport from eastern countries is suspected as seen from back trajectories calculations by Ancellet et al. (2008). Such significant levels reveal that MCS might have influenced the free troposphere by uplifting NMHC from the lower troposphere. Although concentration levels generally decrease with altitude, significant levels were observed during this campaign, in the middle and upper troposphere. In fact, the tropical troposphere is thought to be frequently influenced by recent convective activity, transporting important levels of these species to the upper layers. 

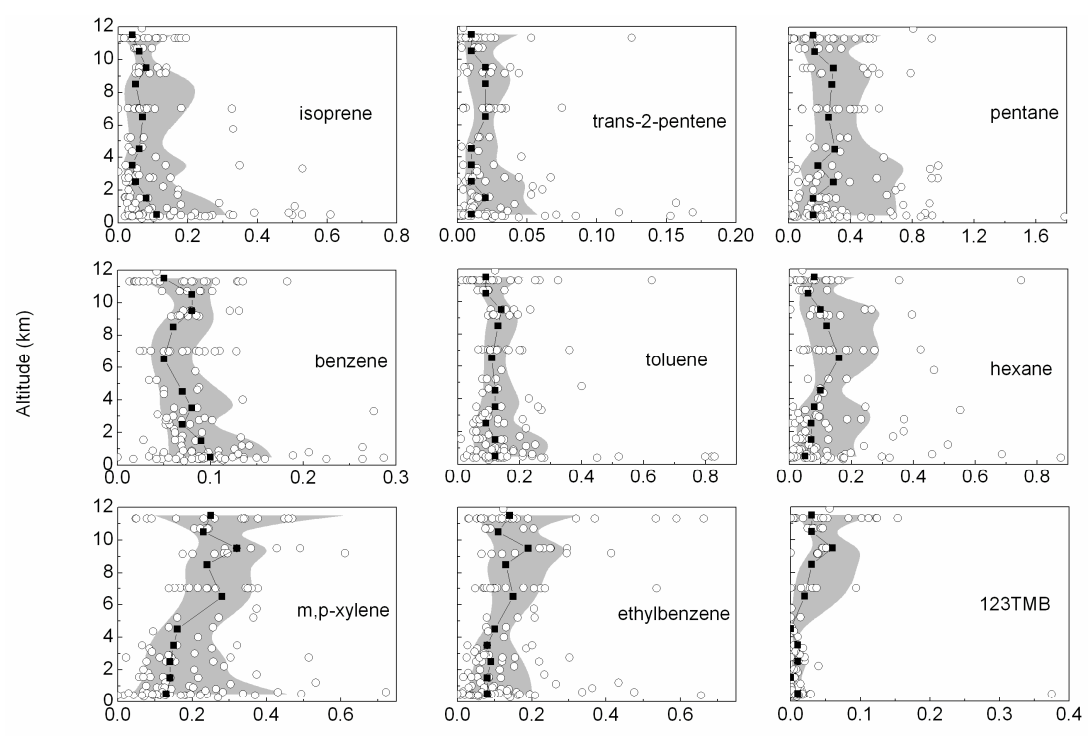

Mixing ratio $(\mathrm{ppb})$

Fig. 3. Vertical profiles of a selection of NMHC collected on both aircrafts during SOP 2a2. Open markers are all observations. Black markers are average values in altitude bins of $1 \mathrm{~km}$. Grey area represents standard deviations for all observations.

Finally, NMHC profile analysis highlights factors that concurrently influence NMHC distribution over West Africa: chemical loss, long range transport of polluted air masses, deep convection and biomass burning intrusion in the region.

\section{Indicators used for classification of MCS impacted air masses}

Sampled air masses in the UT have different origins (convective transport, biomass burning or long range transport) that could impact trace gases variability as revealed by NMHC observations in Sect. 4. Air masses classification is essential in order to distinguish between conditions perturbed by convection from those non-perturbed by convection. For that purpose, a multiple chemical and physical tracers approach has been taken using $\mathrm{CO}, \mathrm{O}_{3}$ and $\mathrm{RH}$ as indicators. Apart from their properties that will be discussed further, tracer selection criteria are: (i) high sampling time resolution (1$30 \mathrm{~s}$ ) and (ii) atmospheric lifetime longer than MCS duration ( 2 months for $\mathrm{CO}$ and several days for $\mathrm{O}_{3}$ ) (Dickerson et al., 1987; Dessler, 2002; Folkins et al., 2002; Lawrence and Salzmann, 2008).

Convective conditions are characterized by concurrent high $\mathrm{CO}$, low $\mathrm{O}_{3}$ and high RH in the air masses (Fig. 4, red lines). $\mathrm{CO}$ concentrations might reach $200 \mathrm{ppb}$, almost as large as those observed in LT, giving a "C"'-shaped profile to $\mathrm{CO}$ vertical distribution. $\mathrm{O}_{3}$ values are lower in MCS outflow $(30 \mathrm{ppb})$ than outside it $(50 \mathrm{ppb})$ because of the input of low- $\mathrm{O}_{3}$ air masses from near the surface. $\mathrm{O}_{3}$ follows an "S-shaped" profile in convective situations. $\mathrm{RH}$ is enhanced in the UT reaching values up to $80 \%$ as a signature of cloud presence as well as uplift of humid air masses from surface layers. These concomitant alterations in tracer levels point out important uplift of LT air by the MCS up to the UT and characterize convective air masses.

Average $\mathrm{CO}, \mathrm{O}_{3}$ and $\mathrm{RH}$ vertical patterns collected during all deployments of the ATR-42 and the F-F20 are discussed in details in Reeves et al. (2010) and Ancellet et al. (2008). Here, only average features are described. $\mathrm{CO}$ is produced primarily by incomplete combustion through urban areas and biomass burning emissions. Its major sink is the reaction with $\mathrm{OH}$, followed by surface deposition (Hauglustaine et al., 1998; Granier et al., 2000). Because CO is destroyed through the troposphere, its concentrations are expected to decrease with altitude. In typical average background conditions during SOP 2a2, CO shows values of about $120 \pm 18 \mathrm{ppb}$ in LT increasing to $200 \mathrm{ppb}$ over the two main cities (Niamey, Cotonou) (Fig. 4). In upper layers (4-12 km), CO gradually decreases to $100 \pm 10 \mathrm{ppb}$.

Tropospheric $\mathrm{O}_{3}$ is produced in situ through $\mathrm{NO}_{\mathrm{x}}$, VOC and $\mathrm{CO}$ photochemistry and, to a lesser extent, due to stratospheric intrusions. The major $\mathrm{O}_{3}$ sink is surface deposition. As a consequence, $\mathrm{O}_{3}$ is expected to increase with altitude. During SOP 2a2, average $\mathrm{LT}_{3}$ concentrations show relatively little variation with values of $30 \pm 10 \mathrm{ppb}$. The lowest values $(20 \mathrm{ppb})$ were detected above the forest region $\left(7-11^{\circ} \mathrm{N}\right)$ where $\mathrm{O}_{3}$ deposition is enhanced by vegetation. Highest values $(70 \mathrm{ppb})$ were detected near the urban sites of Niamey and Cotonou. In upper layers $(2-12 \mathrm{~km}), \mathrm{O}_{3}$ increases with altitude up to $60 \mathrm{ppb}$ showing strong variability. 


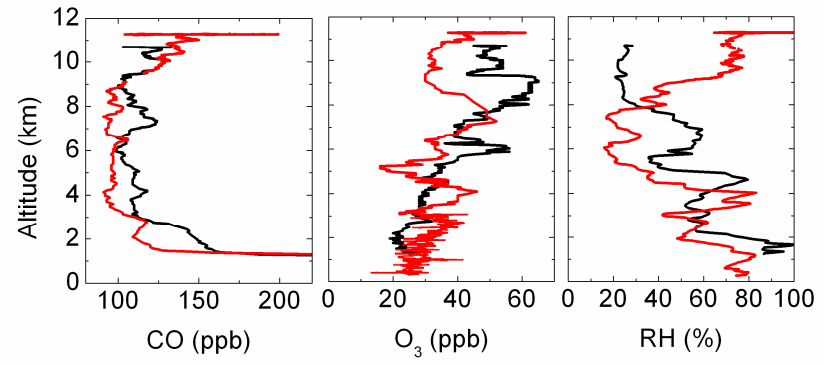

Fig. 4. Vertical profiles of $\mathrm{CO}, \mathrm{O}_{3}$ and $\mathrm{RH}$ used as convection indicators. Black lines (13 August flight) are typical variation in nonconvective conditions. Red lines (14 August flight) are the vertical variations in convective conditions.

Water vapor as indicated by RH gives valuable information on cloud location. In average conditions, RH shows high values $(70 \%)$ in LT particularly above the tropical forest influenced by the wet monsoon flow at latitudes south of $13^{\circ} \mathrm{N}$. North of these latitudes, air masses are dryer $(30 \%)$ due to the arid surface and the influence of the warm and dry Harmattan flow. With altitude, air mass layers get dryer up to $20 \% \mathrm{RH}$.

Non-convective conditions showing profiles as described above were encountered on 13 and 20 August of 2006 (Fig. 4, black lines). Any shape deviation from average profiles can be considered as conditions perturbed by convection or other causes but concomitant variations of tracer vertical shapes are considered as a situation perturbed by convection (Fig. 4, red lines). A summary of the variation of convection indicators for each F-F20 flight is given in Table 3. Four cases were identified on 11, 14, 15 and 17 August 2006 corresponding to outflow explorations where the F-F20 flew in the active MCS. Air masses influenced by biomass burning intrusions have been also detected on the vertical profiles with high $\mathrm{CO}$ levels up to $180 \mathrm{ppb}$ at $9 \mathrm{~km}$ on 19 August near Cotonou (Ancellet et al., 2008). These enhancements are associated with increased $\mathrm{O}_{3}$ levels and lower $\mathrm{RH}$ showing that the use of a single tracer (e.g. CO) is not sufficient for convective case distinction.

Finally, the successful use of multiple chemical and physical indicators made possible a fine distinction between air masses in the cloud outflow perturbed by convection from those outside the outflow and not perturbed by convection (Table 3).

\section{NMHC in the upper troposphere under convective and non-convective conditions}

\subsection{Evidence of deep convection impact on NMHC in the UT}

To address impact of convective injections on NMHC distribution in the UT, we examined: (i) horizontal NMHC distribution, (ii) total NMHC content and (iii) surface NMHC
Table 3. Convection indicators variations for F-F20 flights. $\downarrow$ : decreasing mixing ratios, $\uparrow$ : increasing mixing ratios.

\begin{tabular}{llrrr}
\hline Date & Flight no. & \multicolumn{3}{c}{ Convection indicators } \\
& & $\mathrm{O}_{3}$ & $\mathrm{CO}$ & $\mathrm{RH}$ \\
\hline 11 August 2006 & FV48 & $\sim \downarrow$ & $\uparrow$ & $\uparrow$ \\
13 August 2006 & FV49 & $\uparrow$ & $\downarrow$ & $\downarrow$ \\
14 August 2006 & FV50 & $\downarrow$ & $\uparrow$ & $\uparrow$ \\
15 August 2006 & FV51 & $\sim$ & $\uparrow$ & $\uparrow$ \\
17 August 2006 & FV53 & $\downarrow$ & $\sim \uparrow$ & $\uparrow$ \\
19 August 2006 & FV54 & $\uparrow$ & $\uparrow$ & $\downarrow$ \\
19 August 2006 & FV55 & $\uparrow$ & $\downarrow$ & $\downarrow$ \\
20 August 2006 & FV56 & $\uparrow$ & $\downarrow$ & $\downarrow$ \\
21 August 2006 & FV57 & $\uparrow$ & $\downarrow$ & $\downarrow$ \\
\hline
\end{tabular}

emissions signature in the UT in convective vs. non convective conditions.

i. Horizontal NMHC distribution was examined in the UT along F-F20 MCS flight tracks (e.g. MCS of $15 \mathrm{Au}-$ gust 2006 in Fig. 5 for benzene, toluene and isoprene). NMHC observations are sparse and 10-min-integrated. We overlaid NMHC sampling points on $\mathrm{CO}, \mathrm{O}_{3}$ and $\mathrm{RH}$ data because of their higher measurement frequency (1 s). First, CO shows an important longitudinal positive gradient through the outflow with an increasing trend going up by $30 \%$. Mean $\mathrm{CO}$ longitudinal gradient for the four MCS is $13 \pm 3 \mathrm{ppb}^{\circ} \mathrm{E}^{-1}$ (e.g. $20 \mathrm{ppb}^{\circ} \mathrm{E}^{-1}$ on 15 August flight described in Fig. 5). Gradient calculations are based on observations on the 4 parallel legs made when exploring the MCS. Secondly, no $\mathrm{O}_{3}$ gradient is observed in the outflow but $\mathrm{O}_{3}$ concentrations are sensitive to cloud position. They are smaller inside the outflow (about $45 \mathrm{ppb}$ ) than outside it (about $60 \mathrm{ppb}$ ) because of the injection of low- $\mathrm{O}_{3}$ and humid air masses from LT. The absence of trend in $\mathrm{O}_{3}$ observations points out the dual nature of tropical convection. Convection impact on $\mathrm{O}_{3}$ distribution almost shows a negative trend locally but fills the UT with $\mathrm{O}_{3}$ precursors that will potentially lead to delayed $\mathrm{O}_{3}$ production downwind the MCS (Folkins et al., 2002). Finally, RH values are also sensitive to MCS inflow and outflow position with higher values close to saturation inside the MCS (>80\%). Compared to convection tracers, NMHC observations do not exhibit any meaningful trend. Values show great variability without any horizontal gradient.

ii. While NMHC longitudinal distribution do not show a clear trend, total NMHC content is clearly affected by convection compared to non perturbed conditions. Box plots are reported for selected NMHC in Fig. 6 and sorted by non-convective, convective UT and LT observations. For all NMHC, mixing ratio distributions 


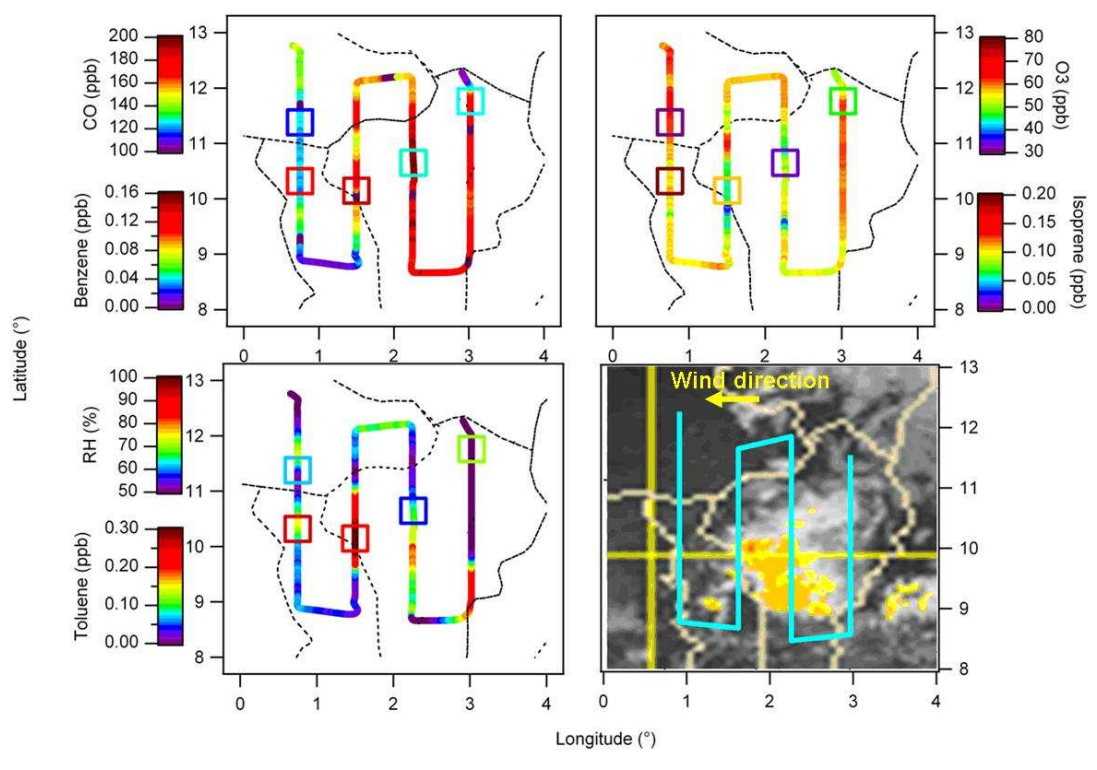

Fig. 5. Latitude vs. longitude distribution at UT level for $\mathrm{CO}$ (top left panel), $\mathrm{O}_{3}$ (top right panel), RH (bottom left panel) in full line, and benzene (top left panel), isoprene (top right panel) and toluene (bottom left panel) in squares. The boxes location corresponds to the middle of the sampling time of $10 \mathrm{~min}$. Each flight leg corresponds to $30 \mathrm{~min}$. Flight track is superimposed on the Meteosat satellite picture at 14:00 UTC in bottom right panel. The flight took place on 15 August between 12:35 UTC and 16:57 UTC.

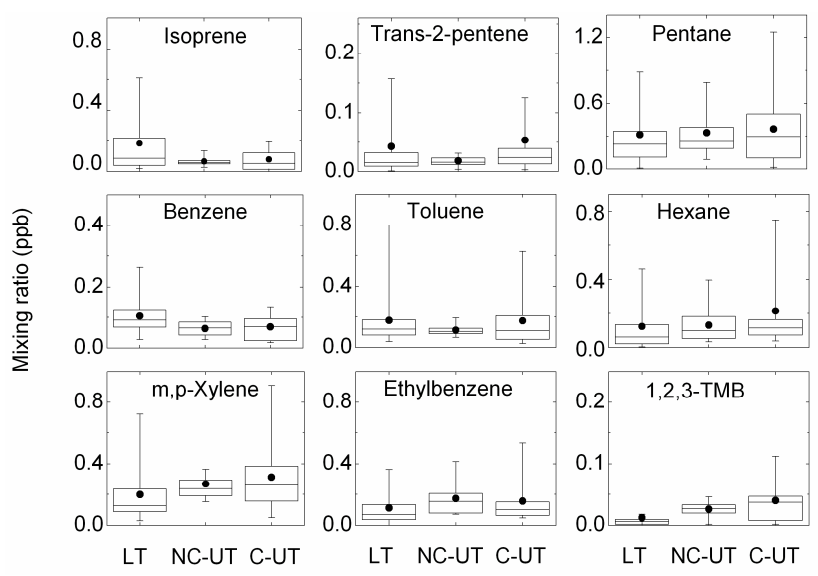

Fig. 6. Selected NMHC variability in the low troposphere (LT) (94 data points), in non-convective UT (NC-UT) (34 data points) and in convective UT (C-UT) (25 data points). Lower and upper limits of the box correspond to $25 \%$ and $75 \%$ percentiles, bottom and top whiskers the $10 \%$ and $90 \%$. Middle bars indicate the median and black dots the mean.

are more scattered in convective cases and similar to LT distribution. In non-convective cases, distribution is tighter. Average UT mixing ratios can double in convective outflow compared to non-perturbed air masses. Mixing ratios variability is different from one NMHC to another as well as from an MCS to another illustrating the heterogeneity of these systems as well as NMHC lifetimes making their chemical signature more or less persistent. Nevertheless, NMHC concentrations are significantly enhanced by convective injection in the UT. Moreover these injections are dissimilar all over the convective cloud anvil.

iii. Significant NMHC levels in convective UT are expected to come from surface emissions. Since vegetation gradient and surface coverage are critical factors governing NMHC latitudinal composition (see Sect. 5.2), we investigated surface emissions influence on NMHC outflow composition. Satellite MCS tracking images provide information on the region where the MCS started to develop as well as its trajectory before being sampled. As MCS have westward motion, the latitude where they started to develop (called latitude zero here after) indicates the nature of the surface it passed through and is used as a proxy of emissions (Fig. 1). On $11 \mathrm{Au}-$ gust, the MCS started to develop above Nigeria over a forested region and passed over Benin before being sampled around Niamey (FV48). On 14 August, the MCS started to develop east of Niamey above Sahel and moved westward to Niamey where it was explored (FV50). On 15 August, the MCS developed over a forested region in Benin and was explored south of Niamey (FV51). On 17 August, the MCS started to develop in the Airr region north of Niamey above Sahel (FV53). Mean NMHC levels for isoprene and benzene in the MCS outflow are reported according to latitude zero in Fig. 7. Isoprene levels show exponential dependence on surface characteristics. Both MCS that 


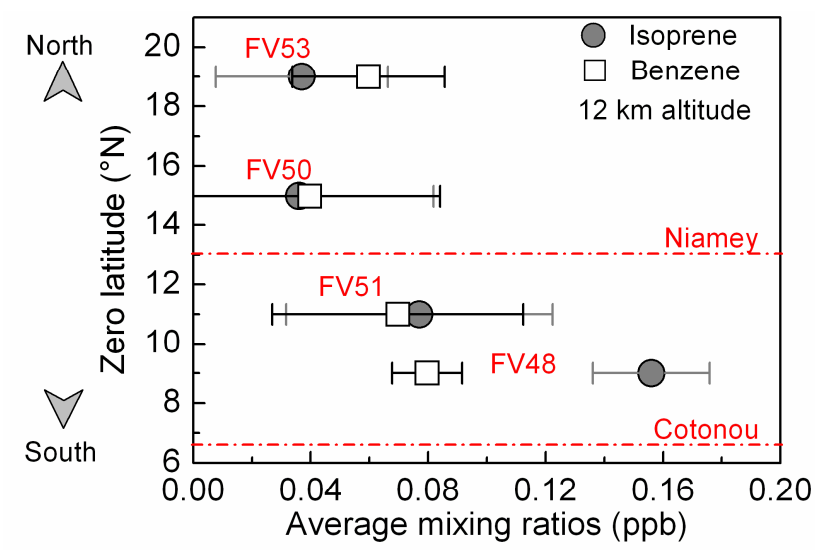

Fig. 7. Average UT content (FV48: 4 data points, FV50: 4 data points, FV51: 4 data points, FV53: 5 data points) of isoprene (round marker) and benzene (squared marker) according to latitude zero. Bars indicate standard deviations.

developed over forested regions (FV48 and FV51) have isoprene content up to three times higher than the MCS that developed over the Sahel (FV50 and FV53). A different trend is observed for anthropogenic compounds such as benzene. Average benzene contents are rather homogeneous regarding the 4 MCS. Indeed, urban areas, which are benzene main sources in the domain, are limited and located at specific spots (Niamey $13^{\circ} 51 \mathrm{~N}-$ $2.11^{\circ} \mathrm{E}$, Cotonou $6.3^{\circ} \mathrm{N}-2.4^{\circ} \mathrm{E}$, Lagos $6.4^{\circ} \mathrm{N}-3.4^{\circ} \mathrm{E}$ ) while vegetation coverage follows a smooth north to south gradient. These observations highlight the influence of surface sources on the UT NMHC content mediated by convection.

The investigation of NMHC content in non-convective vs. convective conditions and its dependence on surface coverage reveals that deep convection increases NMHC content in the UT over West Africa.

\subsection{Photochemistry vs. transport regimes in West Africa UT for NMHC}

Being reactive species, NMHC can be used as tracers of photochemical and transport processes governing trace gases variability. In particular, NMHC ratios with common sources and different atmospheric lifetimes provide further information on the degree of atmospheric processing in sampled air masses. NMHC ratios are then useful photochemical clocks to qualitatively follow transport and ageing of air masses (Borbon et al., 2004). We examined trans-2-pentene to benzene and toluene vs. benzene ratios from UT observations to differentiate regimes controlling NMHC distribution. Natural logarithms of trans-2-pentene/benzene vs. toluene/benzene ratios are plotted in Fig. 8. Trans-2-pentene is one of the most reactive measured NMHC (lifetime of few hours), toluene is of medium reactivity (lifetime of 2 days)

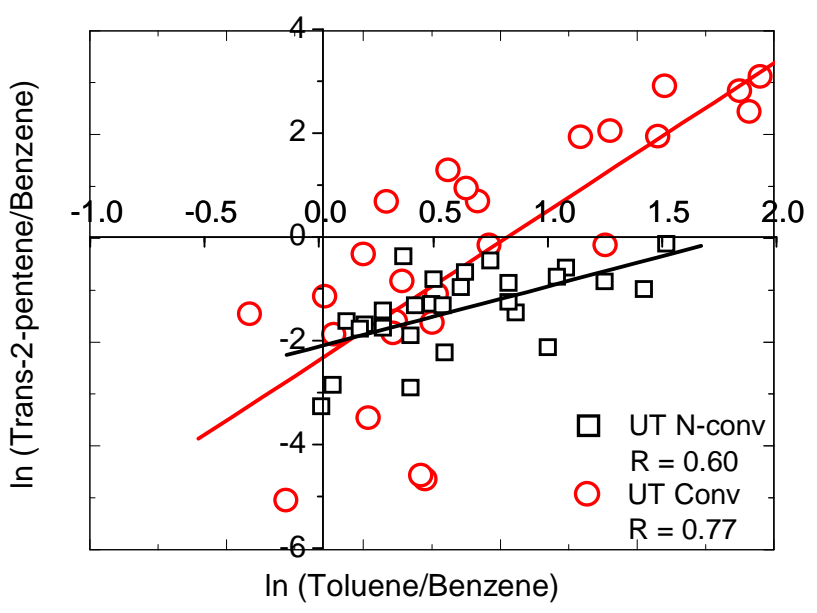

Fig. 8. Natural logarithms of trans-2-pentene to benzene vs. toluene to benzene ratios for F-F20 observations in the UT. Concentrations ratios are shown in black markers in non-convective conditions and in red markers during convective conditions. Lines show linear fits for each data set.

and benzene is the least reactive NMHC (lifetime of 9 days). The least reactive NMHC (benzene) being at the denominator, the fresher air masses are, the greater the ratios are.

Clearly, two sets of points are distinguished in Fig. 8 depending on non-convective situations (black) and convective situations (red). An analysis of variance (ANOVA) show that the two data sets are statistically distinct since calculated $F=4.852>F_{0}=4.030$. Each data set shows a linear relationship with correlation factor of 0.60 and 0.77 respectively. Data in non-convective situations are scattered along toluene/benzene axis and have a slope of 1.16 and denotes chemical processing on several days. This agrees well with aged air masses composition with low trans-2pentene mixing ratios close to DL after several days of photochemical processing. The scatter plot in the convective situation is more scattered with greater data variability along toluene/benzene axis as well as along trans-2pentene/benzene axis that denotes chemical processing in fresh air masses. Ratios display the highest ratios values and the slope exhibits a greater value (2.87) illustrating the freshness of sampled convective outflow enriched with reactive species such as trans-2-pentene. UT NMHC concentrations are thus governed by two distinct regimes that are affected by convective injections.

The theoretical slope is expected to equal 13 when all assumptions (no dilution or mixing, ratios are only governed by chemistry regarding $\mathrm{OH}$ ) are considered. Since the slope values are far from the theoretical value, we deduce that dilution and mixing could not be neglected. Moreover, the lower the slope is the more processed the air mass is, diluted and mixed with other air masses of different photochemical ages. 
Even with the complexity of the different processes in the upper tropospheric region, the NMHC ratio provides a qualitative evaluation of the photochemical and dynamical processing in the air masses.

\subsection{Impact of deep convection on air mass reactivity}

$\mathrm{OH}$ reactivity is used to evaluate the contribution of measured NMHC to photochemical activity. OH reactivity is also an indicator of the $\mathrm{O}_{3}$ chemical production contribution. Here, estimated reactivity is based on NMHC measurements on board the ATR-42 and the F-F20. Individual NMHC reactivity $\left(R_{\mathrm{OH}, i}\right)$ is calculated using Eq. (1):

$$
R_{\mathrm{OH}, i}=k_{\mathrm{OH}, i}\left[\mathrm{NMHC}_{i}\right]
$$

where $k_{i, \mathrm{OH}}$ is the $\mathrm{OH}$ reaction rate coefficients for every NMHC taken from Atkinson (2003); Atkinson et al. (2006) and calculated for LT and UT temperatures; $\left[\mathrm{NMHC}_{i}\right]$ is the mixing ratio of the target observed NMHC.

Total NMHC reactivity ( $\left.R_{\mathrm{OH}, \text { total }}\right)$ is derived from the sum of individual $R_{\mathrm{OH}, i}$ using Eq. (2) of each measured compounds (total of 15 compounds). The reactivity here calculated is then the contribution of the gases we measured to the total reactivity; it does not take into account methane or other non-measured reactive gases.

$$
R_{\mathrm{OH}, \text { total }}=\sum R_{\mathrm{OH}, i}
$$

While this approach gives a practical estimate of the contribution of measured NMHC to the atmospheric photochemistry; it does not explain the full atmospheric chemistry of the considered compounds.

UT air mass reactivity calculated for convective cases is compared to air masses reactivity for non-convective cases and for the LT (Fig. 10). In non-convective conditions, UT $R_{\mathrm{OH} \text {,total }}$ is $0.52 \pm 0.21 \mathrm{~s}^{-1}$ while it raises in convective conditions up to $0.95 \pm 0.66 \mathrm{~s}^{-1}$. Thus, air masses reactivity is enhanced by $40 \%$ in the UT due to injection of reactive NMHC. During convective events, UT $R_{\mathrm{OH} \text {,total is a similar }}$ value to the LT one which equals $0.82 \pm 0.53 \mathrm{~s}^{-1}$.

The relative contribution of each $\mathrm{NMHC}, \mathrm{CO}$ and $\mathrm{O}_{3}$ to $R_{\mathrm{OH} \text {,total }}$ is evaluated according to altitude. The vertical profile of relative contributions to $R_{\mathrm{OH} \text {,total }}$ is reported in Fig. 9 .

Isoprene is the main reactant with $\mathrm{OH}$ at all altitudes, providing the greatest part of the total reactivity which is of $0.90 \mathrm{~s}^{-1}$ in LT (49\%) and $1.00 \mathrm{~s}^{-1}$ in the UT $(33 \%)$. The sum of other NMHC contributions is $48 \%$ in LT and $65 \%$ in the UT. As expected, $\mathrm{O}_{3}$ and $\mathrm{CO}$ exhibit a negligible contribution of a few percent $(\leq 3 \%)$. These results show that NMHC play an important role in air masses reactivity and tropical UT photochemical potential which is expected to induce changes in ozone chemistry. Absolute UT $R_{\mathrm{OH}}$ value during AMMA is consistent with the one calculated by Mao et al. (2009) during INTEX-B (mid-latitude UT) with values less than $1 \mathrm{~s}^{-1}$. Nevertheless, $\mathrm{CO}$ is by far the major contributor during INTEX-B making $60 \%$ of $\mathrm{OH}$ reactivity due

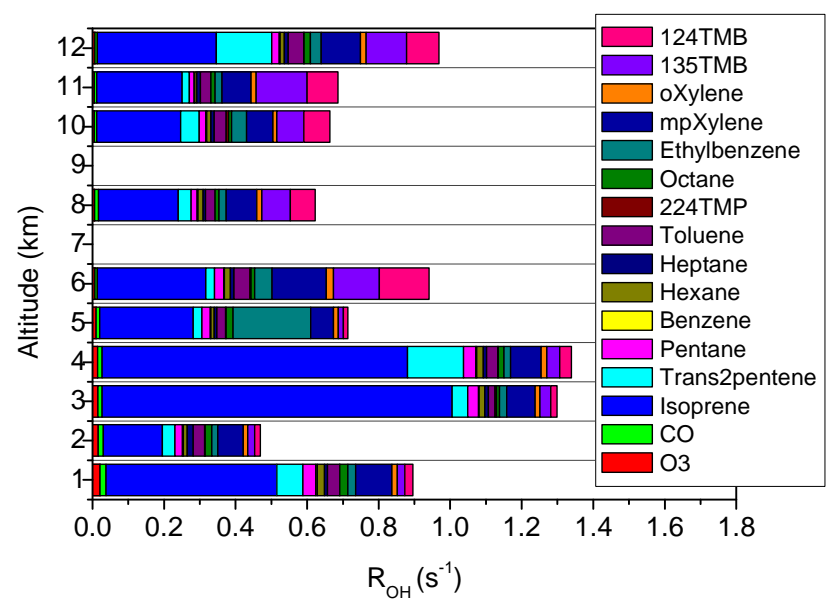

Fig. 9. Vertical profiles of $\mathrm{O}_{3}, \mathrm{CO}$ and NMHC contribution to total reactivity $R_{\mathrm{OH}}$. Average are calculated at altitudes ranges of 0 $1 \mathrm{~km}$ (54 data points), $1-2 \mathrm{~km}$ (18 data points), $2-3 \mathrm{~km}$ (13 data points), 3-4 km (9 data points), 4-5 km (5 data points), 5-6 km (3 data points), $7-8 \mathrm{~km}$ (6 data points), $9-10 \mathrm{~km}$ (12 data points), 10 $11 \mathrm{~km}$ (5 data points), $11-12 \mathrm{~km}$ (22 data points).

to different location (Asian pollution outflow) and more processed air masses. NMHC may have already reacted, $\mathrm{CO}$ being stable and by-product of NMHC oxidation.

\subsection{Fraction of low tropospheric air in fresh convective outflow}

To obtain a quantitative evaluation on vertical transport impact and to assess to the extent to which the LT air affects the UT; we calculated the fraction $f$ of LT air in the fresh convective outflow. To calculate $f$, we applied NMHC observations to Eq. (3) adapted from Bertram et al. (2007).

$f=\frac{[\mathrm{UT}] \text { outflow }-[\mathrm{UT}] \text { bckgrd }}{[\mathrm{LT}]-[\mathrm{UT}] \text { bckgrd }}$

where [UT] outflow is the mean mixing ratio of a selected compound in fresh convective outflow, [UT]bckgrd is the mean mixing ratio in non-convective UT and [LT] is nearsurface mean mixing ratio (below $2 \mathrm{~km}$ ) according to the latitudinal gradient and MCS trajectory using "latitude zero"(cf. Sect. 6.1). The method presumes that photochemical loss is negligible during vertical transport, chemical lifetimes of species being longer or equivalent to vertical transport timescales $(\sim 30 \mathrm{~min})$. First, we calculated $f$ for each individual NMHC (15 compounds). Then we averaged $f$ combining all the individual results for each of the 4 MCS (Fig. 11, left). $f$ values are of $37 \pm 1 \%$ for $\mathrm{FV} 48,44 \pm 13 \%$ for FV50, $29 \pm 14 \%$ fro FV51 and $48 \pm 12 \%$ for FV53. The overall mean of $f$ is about $40 \pm 15 \%$ (Fig. 11). The variability $( \pm 15 \%)$ is the standard deviation of the average of all calculated fractions. Results are consistent regarding the 4 MCS explored during SOP $2 \mathrm{a} 2$ as well as with other studies at mid-latitude (10 to $40 \%$ by Ray et al., $2004 ; 17 \%$ by 


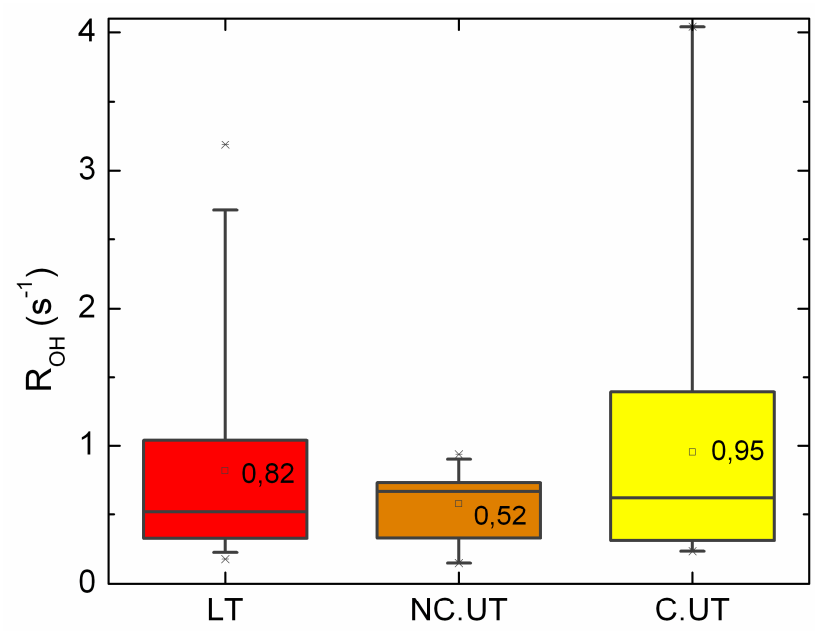

Fig. 10. Total NMHC reactivity according to $\mathrm{OH}$ radical in the boundary layer (LT, in red, 58 data points) and in the UT during non-convective (NC.UT in orange, 20 data points) and convective (C.UT, in yellow, 29 data points) situations.

Bertram et al., 2007) and in marine tropical regions (32 to $64 \%$ by Cohan et al., 1999). As expected, tropical deep convection above continent is more vigorous than at mid-latitude regions and weaker than marine tropical convection where larger humidity amounts are available.

\subsection{Vertical transport timescale during convective events}

Vertical transport timescale estimation is based on an original approach using the photochemical processing equation with isoprene and benzene observations. Here, we assume that photochemical loss of isoprene is of similar timescale to that of a convective event. Therefore, isoprene (lifetime of few hours) is considered to be an efficient tracer of vertical transport. Air masses were also sampled immediately in the outflow after detrainment in a time range of a few minutes. Consequently, a calculated time based on the photochemical processing equation can be attributed to the vertical pumping. Depending on the reactivity of the species relative to $\mathrm{OH}$, the photochemical age $\Delta t$ can be determined by Eq. (4),

$\Delta t=\frac{\ln \left[\frac{\text { (Isoprene/Benzene)PBL }}{\text { (Isoprene/Benzene)UT }}\right]}{\left(k_{i}-k_{b}\right)[\mathrm{OH}]}$

where [isoprene] and [benzene] are the mixing ratio of isoprene and benzene in LT and in the convective outflow, $k_{i}$ and $k_{b}$ are the $\mathrm{OH}$ reaction rate constants for isoprene and benzene respectively $\left(k_{i}=1.0 \times 10^{-10} \mathrm{~cm}^{3} \mathrm{molec}^{-1} \mathrm{~s}^{-1} ; k_{b}=\right.$ $1.2 \times 10^{-12} \mathrm{~cm}^{3} \mathrm{molec}^{-1} \mathrm{~s}^{-1}$; taken from Atkinson, 2003; Atkinson et al., 2006) and [OH] is $\mathrm{OH}$ radical mean concentration. Since a large uncertainty remains in $\mathrm{OH}$ concentrations due to its large variability and lack in measurements, we considered $[\mathrm{OH}]$ to be $2.10^{6}$ molecules $\mathrm{cm}^{-3}$ in the low

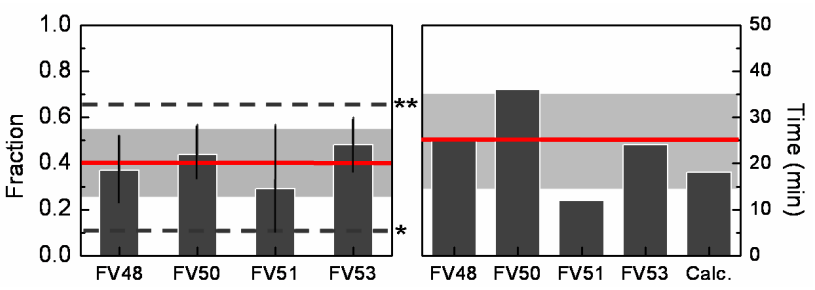

Fig. 11. Deep convection characteristics in West Africa. Left plot: fraction of low tropospheric air in fresh convective outflow for each MCS. Vertical bar is the standard deviation of the average of all calculated fractions with the different NMHC, the red line is the global mean fraction, the grey area is the standard deviation of the global mean fraction, the dashed lines are the minimum and maximum fraction value reported in the literature. * Ray et al., 2004 in mid-latitude convection, ${ }^{* *}$ Cohan et al., 1999 in marine tropical convection. Right plot: vertical transport timescale for each MCS compared to theoretical time (Calc.) calculated (vertical wind speed of $15 \mathrm{~m} \mathrm{~s}^{-1}, 12 \mathrm{~km}$-altitude). The red line indicates mean transport time, the grey area is the standard deviation of the mean transport time.

troposphere in tropical regions on the basis of Lawrence et al. (2001). OH concentration is also assumed to be constant at all altitudes during vertical transport.

$\Delta t$ ranges from 12 to $36 \mathrm{~min}$ for the $4 \mathrm{MCS}$ with an average of $25 \pm 10 \mathrm{~min}$ (Fig. 11, right). Results are consistent with the expected timescale of vertical transport by deep convection (15-20 min) derived from typical vertical velocities (5-15 $\mathrm{m} \mathrm{s}^{-1}$ ) (Fig. 11) and with modeling studies by Thompson et al. (1997) (30 min). It should be noted that there is a high uncertainty in the assumed $\mathrm{OH}$ concentration .By assuming that $[\mathrm{OH}]$ could be divided by 2 $\left([\mathrm{OH}]=10^{6}\right.$ molecules $\left.\mathrm{cm}^{-3}\right)$, time will then be multiplied by 2 and will reach $50 \mathrm{~min}$ which is still fast compared to the typical vertical transport timescale which is about 1 month. The use of photochemical processing equation based on isoprene and benzene ratios is efficient to calculate vertical transport timescale in a convective system.

\section{Conclusions}

Airborne measurements of tropospheric trace gases species collected by the two French aircrafts during AMMA SOP 2a2 in August 2006 are presented in this paper. These observations constitute a unique data set combining lower and upper tropospheric measurements over a large domain in West Africa. In particular, VOC (NMHC from C5 to C9) are reported from the boundary layer to the UT.

First, NMHC distributions were investigated. NMHC latitudinal distribution is closely connected to land surface characteristics over West Africa with an important north-to-south gradient going from bare soils over Sahel (North) to the tropical forest (South) with limited urban sites (Niamey and 
Cotonou). Biogenic compound concentrations (isoprene) exhibit an important north-to-south gradient following vegetation densification. Anthropogenic species concentrations are at maximum levels over urban sites and decrease over the forest. Vertical NMHC distributions show a "C-shaped" profile with significant UT concentrations due to convective injections and comparable to those observed near the surface, even for the most reactive NMHC.

Then, various diagnostics tools were set up and successfully applied to highlight the impact and characteristics of deep convection on NMHC. $\mathrm{CO}, \mathrm{O}_{3}$ and $\mathrm{RH}$ were used as simultaneous deep convection indicators to isolate convection impacted air masses. UT NMHC concentrations in WA appear to be controlled by two regimes: photochemistry and fast convective vertical transport. NMHC UT concentrations double when subject to convection and are dependent on MCS geographical origin, used as a proxy of surface type, indicating the vertical transport of near-surface air masses. As a consequence, UT total air masses reactivity regarding $\mathrm{OH}$ radical doubles in convective conditions $\left(0.95 \mathrm{~s}^{-1}\right)$ compared to non-convective conditions $\left(0.52 \mathrm{~s}^{-1}\right)$ and reaches values similar to LT reactivity $\left(0.82 \mathrm{~s}^{-1}\right)$. Furthermore, isoprene plays an important role in total reactivity throughout the vertical tropospheric column, especially in convective outflow explaining $27 \%$ of UT total reactivity.

Finally, the fraction of LT air in convective outflow and vertical transport time scale derived from NMHC observations were estimated to be $40 \pm 15 \%$ and $25 \pm 10 \mathrm{~min}$, respectively.

NMHC observations during AMMA reveal the potential impact of deep convection on UT chemistry. Even though ozone production was not directly observed because no flight was performed in aged outflow, post convective ozone formation is expected due to injection of reactive ozone precursors in the UT. Andrés-Hernández et al. (2009) show this ozone formation in MCS outflow during flights performed on-board the DLR-F20 within AMMA campaign and estimate $\mathrm{O}_{3}$ production rates around $1 \mathrm{ppb} \mathrm{h}^{-1}$ in the MCS outflow.

Observations like those related in this paper are essential in order to assess the global impact of deep convection on ozone and other photooxidant production. Beyond characterizing local chemical effects, such observations build a database that can be used for relevant parameterization of mesoscale and global CTM models. In particular, deep convection spatial and temporal characteristics derived from NMHC observation in WA will be useful indicators for guiding model parameterizations.

Acknowledgements. This work is supported by the AMMA project. Based on a French initiative, AMMA was built by an international scientific group and is currently funded by a large number of agencies, especially from France, UK, US and Africa. It has been the beneficiary of a major financial contribution from the European Community's Sixth Framework Research Program. Detailed information on scientific coordination and funding is available on the AMMA International web site http://www.amma-international.org.
We would like also to thank SAFIRE (Service des Avions Français Instrumentés pour la Recherche en Environnement) for deploying the research aircrafts.

Edited by: C. Reeves

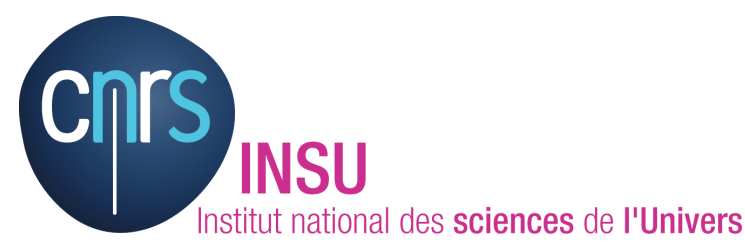

The publication of this article is financed by CNRS-INSU.

\section{References}

Ancellet, G., Leclair de Bellevue, J., Mari, C., Nedelec, P., Kukui, A., Borbon, A., and Perros, P.: Effects of regional-scale and convective transports on tropospheric ozone chemistry revealed by aircraft observations during the wet season of the AMMA campaign, Atmos. Chem. Phys., 9, 383-411, doi:10.5194/acp-9-3832009, 2009.

Andrés-Hernndez, M. D., Kartal, D., Reichert, L., Burrows, J. P., Meyer Arnek, J., Lichtenstern, M., Stock, P., and Schlager, H.: Peroxy radical observations over West Africa during AMMA 2006: photochemical activity in the outflow of convective systems, Atmos. Chem. Phys., 9, 3681-3695, doi:10.5194/acp-93681-2009, 2009.

Atkinson, R.: Kinetics of the gas-phase reactions of $\mathrm{OH}$ radicals with alkanes and cycloalkanes, Atmos. Chem. Phys., 3, 2233 2307, doi:10.5194/acp-3-2233-2003, 2003.

Atkinson, R., Baulch, D. L., Cox, R. A., Crowley, J. N., Hampson, R. F., Hynes, R. G., Jenkin, M. E., Rossi, M. J., Troe, J., and IUPAC Subcommittee: Evaluated kinetic and photochemical data for atmospheric chemistry: Volume II - gas phase reactions of organic species, Atmos. Chem. Phys., 6, 3625-4055, doi:10.5194/acp-6-3625-2006, 2006.

Bechara, J., Borbon, A., Jambert, C., and Perros, P. E.: New off-line aircraft instrumentation for non-methane hydrocarbon measurements, Anal. Bioanal. Chem., 392, 865-876, 2008.

Bertram, T. H., Perring, A. E., Wooldridge, P. J., Crounse, J. D., Kwan, A. J., et al.: Direct measurements of the convective recycling of the upper troposphere, Science, 315, 816-820, 2007.

Borbon, A., Coddeville, P., Locoge, N., and Galloo, J. C.: Characterising sources and sinks of rural VOC in eastern France, Chemosphere, 57, 931-942, 2004.

Carter, W. P. L.: Development of Ozone Reactivity Scales for Volatile Organic-Compounds, J. Air Waste Manage. Assoc., 44, 881-899, 1994.

Cohan, D. S., Schultz, M. G., Jacob, D. J., Heikes, B. G., and Blake, D. R.: Convective injection and photochemical decay of peroxides in the tropical upper troposphere: Methyl iodide as a tracer of marine convection, J. Geophys. Res.-Atmos., 104, 5717-5724, 1999.

Colomb, A., Williams, J., Crowley, J., Gros, V., Hofmann, R., et al.: Airborne measurements of trace organic species in the upper tro- 
posphere over Europe: the impact of deep convection, Environ. Chem., 3, 244-259, 2006.

Dessler, A. E.: The effect of deep, tropical convection on the tropical tropopause layer, J. Geophys. Res.-Atmos., 107(D3), 4033, doi:10.1029/2001JD000511, 2002.

Dickerson, R. R., Huffman, G. J., Luke, W. T., Nunnermacker, L. J., Pickering, K. E., et al.: Thunderstorms - an Important Mechanism in the Transport of Air-Pollutants, Science, 235, 460-464, 1987.

Doherty, R. M., Stevenson, D. S., Collins, W. J., and Sanderson, M. G.: Influence of convective transport on tropospheric ozone and its precursors in a chemistry-climate model, Atmos. Chem. Phys., 5, 3205-3218, doi:10.5194/acp-5-3205-2005, 2005.

Fischer, H., de Reus, M., Traub, M., Williams, J., Lelieveld, J., de Gouw, J., Warneke, C., Schlager, H., Minikin, A., Scheele, R., and Siegmund, P.: Deep convective injection of boundary layer air into the lowermost stratosphere at midlatitudes, Atmos. Chem. Phys., 3, 739-745, doi:10.5194/acp-3-739-2003, 2003.

Folkins, I., Braun, C., Thompson, A. M., and Witte, J.: Tropical ozone as an indicator of deep convection, J. Geophys. Res.Atmos., 107(D13), 4184, doi:10.1029/2001JD001178, 2002.

Ganzeveld, L., Eerdekens, G., Feig, G., Fischer, H., Harder, H., Königstedt, R., Kubistin, D., Martinez, M., Meixner, F. X., Scheeren, H. A., Sinha, V., Taraborrelli, D., Williams, J., VilàGuerau de Arellano, J., and Lelieveld, J.: Surface and boundary layer exchanges of volatile organic compounds, nitrogen oxides and ozone during the GABRIEL campaign, Atmos. Chem. Phys., 8, 6223-6243, doi:10.5194/acp-8-6223-2008, 2008.

Granier, C., Pétron, G., Müller, J.-F., and Brasseur, G.: The impact of natural and anthropogenic hydrocarbons on the tropospheric budget of carbon monoxide, Atmos. Environ., 34, 5255-5270, 2000 .

Guenther, A., Karl, T., Harley, P., Wiedinmyer, C., Palmer, P. I., and Geron, C.: Estimates of global terrestrial isoprene emissions using MEGAN (Model of Emissions of Gases and Aerosols from Nature), Atmos. Chem. Phys., 6, 3181-3210, doi:10.5194/acp-63181-2006, 2006.

Hao, W. M., Ward, D. E., Olbu, G., and Baker, S. P.: Emissions of $\mathrm{CO}_{2}, \mathrm{CO}$, and hydrocarbons from fires in diverse African savanna ecosystems, J. Geophys. Res.-Atmos., 101, 23577-23584, 1996.

Hauf, T., Schulte, P., Alheit, R., and Schlager, H.: Rapid vertical trace gas transport by an isolated midlatitude thunderstorm, J. Geophys. Res., 100(D11), 22957-22970, doi:10.1029/95JD02324, 1995.

Hauglustaine, D. A., Brasseur, G. P., Walters, S., Rasch, P. J., Muller, J. F., Emmons, L. K., and Carroll, C. A.: MOZART, a global chemical transport model for ozone and related chemical tracers 2. Model results and evaluation, J. Geophys. Res.-Atmos., 103, 28291-28335, 1998

Houze, R. A.: Mesoscale convective systems, Rev. Geophys., 42, RG4003, doi:10.1029/2004RG000150, 2004.

Karl, T. G., Christian, T. J., Yokelson, R. J., Artaxo, P., Hao, W. M., and Guenther, A.: The Tropical Forest and Fire Emissions Experiment: method evaluation of volatile organic compound emissions measured by PTR-MS, FTIR, and GC from tropical biomass burning, Atmos. Chem. Phys., 7, 5883-5897, doi:10.5194/acp-7-5883-2007, 2007.

Kesselmeier, J., Kuhn, U., Wolf, A., Andreae, M. O., Ciccioli, P., et al.: Atmospheric volatile organic compounds (VOC) at a remote tropical forest site in central Amazonia, Atmos. Environ., 34, 4063-4072, 2000.

Lafore, J. P. and Moncrieff, M. W.: A Numerical Investigation of the Organization and Interaction of the Convective and Stratiform Regions of Tropical Squall Lines, J. Atmos. Sci., 46, 521-544, 1989.

Lawrence, M. G. and Salzmann, M.: On interpreting studies of tracer transport by deep cumulus convection and its effects on atmospheric chemistry, Atmos. Chem. Phys., 8, 6037-6050, doi:10.5194/acp-8-6037-2008, 2008.

Lawrence, M. G., von Kuhlmann, R., Salzmann, M., and Rasch, P. J.: The balance of effects of deep convective mixing on tropospheric ozone, Geophys. Res. Lett., 30, 1940, doi:10.1029/2003GL017644, 2003.

Lelieveld, J. and Crutzen, P. J.: Role of Deep Cloud Convection in the Ozone Budget of the Troposphere, Science, 264, 1759-1761, 1994.

Mao, J., Ren, X., Brune, W. H., Olson, J. R., Crawford, J. H., Fried, A., Huey, L. G., Cohen, R. C., Heikes, B., Singh, H. B., Blake, D. R., Sachse, G. W., Diskin, G. S., Hall, S. R., and Shetter, R. E.: Airborne measurement of $\mathrm{OH}$ reactivity during INTEX-B, Atmos. Chem. Phys., 9, 163-173, doi:10.5194/acp-9-163-2009, 2009.

Mari, C. H., Cailley, G., Corre, L., Saunois, M., Attié, J. L., Thouret, V., and Stohl, A.: Tracing biomass burning plumes from the Southern Hemisphere during the AMMA 2006 wet season experiment, Atmos. Chem. Phys., 8, 3951-3961, doi:10.5194/acp-8-3951-2008, 2008

Martin, R. V., Jacob, D. J., Logan, J. A., Bey, I., Yantosca, R. M., et al.: Interpretation of TOMS observations of tropical tropospheric ozone with a global model and in situ observations, J. Geophys. Res.-Atmos., 107, 4351, doi:10.1029/2001JD001480, 2002.

Nedelec, P., Cammas, J.-P., Thouret, V., Athier, G., Cousin, J.-M., Legrand, C., Abonnel, C., Lecoeur, F., Cayez, G., and Marizy, C.: An improved infrared carbon monoxide analyser for routine measurements aboard commercial Airbus aircraft: technical validation and first scientific results of the MOZAIC III programme, Atmos. Chem. Phys., 3, 1551-1564, doi:10.5194/acp-3-15512003, 2003.

Nicholson, S. E.: A revised picture of the structure of the "monsoon" and land ITCZ over West Africa, Clim. Dynam., 32, 11551171, 2009.

Pickering, K. E., Dickerson, R. R., Huffman, G. J., Boatman, J. F., and Schanot, A.: Trace Gas-Transport in the Vicinity of Frontal Convective Clouds, J. Geophys. Res.-Atmos., 93, 759773, 1988

Poisson, N., Kanakidou, M., and Crutzen, P. J.: Impact of nonmethane hydrocarbons on tropospheric chemistry and the oxidizing power of the global troposphere: 3-dimensional modelling results, J. Atmos. Chem., 36, 157-230, 2000.

Ray, E. A., Rosenlof, K. H., Richard, E. C., Hudson, P. K., Cziczo, D. J., et al.: Evidence of the effect of summertime midlatitude convection on the subtropical lower stratosphere from CRYSTAL-FACE tracer measurements, J. Geophys. Res.Atmos., 109, D18394, doi:10.1029/2004JD004655, 2004.

Redelsperger, J. L., Thorncroft, C. D., Diedhiou, A., Lebel, T., Parker, D. J., and Polcher, J.: African monsoon multidisciplinary analysis - An international research project and field campaign, 
B. Am. Meteorol. Soc., 87, 1739-1746, 2006.

Reeves, C. E., Formenti, P., Afif, C., Ancellet, G., Attié, J.-L., Bechara, J., Borbon, A., Cairo, F., Coe, H., Crumeyrolle, S., Fierli, F., Flamant, C., Gomes, L., Hamburger, T., Jambert, C., Law, K. S., Mari, C., Jones, R. L., Matsuki, A., Mead, M. I., Methven, J., Mills, G. P., Minikin, A., Murphy, J. G., Nielsen, J. K., Oram, D. E., Parker, D. J., Richter, A., Schlager, H., Schwarzenboeck, A., and Thouret, V.: Chemical and aerosol characterisation of the troposphere over West Africa during the monsoon period as part of AMMA, Atmos. Chem. Phys., 10, 7575-7601, doi:10.5194/acp-10-7575-2010, 2010.

Saxton, J. E., Lewis, A. C., Kettlewell, J. H., Ozel, M. Z., Gogus, F., Boni, Y., Korogone, S. O. U., and Serça, D.: Isoprene and monoterpene measurements in a secondary forest in northern Benin, Atmos. Chem. Phys., 7, 4095-4106, doi:10.5194/acp-74095-2007, 2007.

Stevenson, D. S., Dentener, F. J., Schultz, M. G., Ellingsen, K., van Noije, T. P. C., et al.: Multimodel ensemble simulations of present-day and near-future tropospheric ozone, J. Geophys. Res.-Atmos., 111, D08301, doi:10.1029/2006JD007100, 2006.

Stickler, A., Fischer, H., Bozem, H., Gurk, C., Schiller, C., Martinez-Harder, M., Kubistin, D., Harder, H., Williams, J., Eerdekens, G., Yassaa, N., Ganzeveld, L., Sander, R., and Lelieveld, J.: Chemistry, transport and dry deposition of trace gases in the boundary layer over the tropical Atlantic Ocean and the Guyanas during the GABRIEL field campaign, Atmos. Chem. Phys., 7, 3933-3956, doi:10.5194/acp-7-3933-2007, 2007.
Stickler, A., Fischer, H., Williams, J., de Reus, M., Sander, R., et al.: Influence of summertime deep convection on formaldehyde in the middle and upper troposphere over Europe, J. Geophys. Res.-Atmos., 111, D14308, doi:10.1029/2005JD007001, 2006.

Ström, J., Fischer, H., Lelieveld, J., and Schröder, F.: In situ measurements of microphysical properties and trace gases in two cumulonimbus anvils over western Europe, J. Geophys. Res., 104(D10), 12221-12226, doi:10.1029/1999JD900188, 1999.

Thompson, A. M., Tao, W. K., Pickering, K. E., Scala, J. R., and Simpson, J.: Tropical deep convection and ozone formation, B. Am. Meteorol. Soc., 78, 1043-1054, 1997.

Warneke, C., Holzinger, R., Hansel, A., Jordan, A., Lindinger, W., et al.: Isoprene and its oxidation products methyl vinyl ketone, methacrolein, and isoprene related peroxides measured online over the tropical rain forest of Surinam in March 1998, J. Atmos. Chem., 38, 167-185, 2001.

Zipser, E. J., Cecil, D. J., Liu, C. T., Nesbitt, S. W., and Yorty, D. P.: Where are the most intense thunderstorms on earth?, B. Am. Meteorol. Soc., 87, 1057-1071, 2006. 